\title{
Д.А. Скулимовская
}

Иркутский государственный лингвистический университет

\section{О разных подходах к изучению предикатов предложений, категоризирующих ситуацию предупреждения}

Аннотация: Статья посвящена изучению классификаций предикатов с семантикой предупреждения. Предикаты рассматриваются как коммуникативные, перформативы и метакоммуникативные, которые предлагается выделять в особую группу, отличающуюся определенными функциональными и структурными свойствами. Особое внимание уделяется определению компонентов ситуации предупреждения.

The article is devoted studying of the classification of predicates with semantics of warning. The predicates are considered as communicative, performatives and metacommunicative which are offered to be allocated in the particular group, differing with certain functional and structural properties. The special attention is given to definition of the components of the situation of warning.

Ключевые слова: метакоммуникативный предикат, коммуникативный предикат, перформатив, метакоммуникация.

Metacommunicative predicate, communicative predicate, performative predicate, metacommunication.

УДК: 81’367.7

Контактная информация: Иркутск, ул. Ленина, 8. ИГЛУ. E-mail: darya_irk@mail.ru.

До настоящего момента глаголы с семантикой предупреждения изучались как перформативы, коммуникативные и оценочные глаголы, в данной статье предлагается рассматривать их в качестве метакоммуникативных предикатов.

В исследованиях коммуникативных глаголов была предложена масса классификаций их по различным признакам. Так некоторые авторы (Л.М. Ковалева, С.К. Воронова, С.А. Крылов) относят коммуникативные предикаты к каузативным на основании того, что основным средством интеллектуальноинформационного влияния на человека является речь. Как отмечает С.А. Крылов, «специфика коммуникативных предикатов в том, что они обозначают целесообразное контролируемое действие - сознательную каузацию тех или иных пропозициональных установок у адресата» [Крылов, 1987, с. 72]. Для коммуникативных предикатов характерно то, что они обозначают целесообразное контролируемое действие - сознательную каузацию тех или иных пропозициональных установок у адресата. Коммуникативная рамка выявляет коммуникативную направленность сообщения: он сказал, что (повествование), он попросил, чтобы (волеизъявление), он спросил, что (вопрос). Автор при этом является носителем коммуникативных намерений и предпринимает усилия, направленные на достижение определенного результата - перлокутивного эффекта, состоящего в том, чтобы Адресат стал, в свою очередь, носителем тех же самых или иных пропозитивных установок. Семантическая структура предложения с каузативным коммуникативным предикатом включает Каузатора-Автора и каузируемое событие (физическое или 
ментальное), субъектом которого является Адресат. С этой точки зрения, предикаты типа to warn являются коммуникативными.

Английские глаголы to warn (предупреждать), to advise (советовать), содержащие в себе сему «предупреждение», также являются перформативами. Дж. Остин первым ввел понятие «перформатив» и изучал явления перформативности, которое послужило отправной точкой в исследовании речевых актов [Austin, 1967]. Глагол считается перформативным, если для него возможно такое употребление формы первого лица единственного числа настоящего времени (несовершенного вида) активного залога индикатива, которое равносильно однократному выполнению обозначаемого этим глаголом действия [Апресян, 1995]. Сравним неперформативный глагол с перформативным:

Я читаю - сообщение об акте чтения, а не акт чтения.

Я предупреждаю - это акт предупреждения, а не сообщение о нем.

Перформативы со стороны наблюдателя переходят в метакоммуникативные предикаты, которые включают в себя оценку ситуации и другие компоненты личности наблюдателя. В современной лингвистике термин «метакоммуникативный предикат» включает в себя понятие «коммуникативный глагол» и позволяет анализировать предикаты в когнитивном аспекте. Однако метапредикаты, обладающие метакоммуникативной природой по форме, принадлежат «внутреннему» языку человека и не являются искусственно созданными [Проскурин]. Метакоммуникативный предикат вводит дополнительную оценочную семантику в передаваемую ситуацию, выбор предиката для передачи сообщения зависит от автора (наблюдателя). Например, можно одну и ту же ситуацию сообщения о злой собаке категоризировать как совет или угрозу. Ср.:

Петр угрожает Марии злой собакой, которую он может спустить.

Петр советует быть осторожнее, потому что он может спустить злую собаку.

Выбор наблюдателем-говорящим предиката зависит от его оценки ситуации, пропущенной через его же когнитивное пространство, на которое влияют многие субъективные факторы, характеристики языковой личности говорящего. Предикаты предупреждать, советовать, угрожать (англ. warn, advise, threaten) не являются синонимичными, но в них содержаться общие, смежные семы.

«Метакоммуникативный предикат репрезентирует действие, при этом, кроме отражения протекающей коммуникативной ситуации, включает прецедентную, т.е. содержит в своей когнитивной структуре одновременно две ситуации, а именно: текущую коммуникативную ситуацию и прецедентную коммуникативную ситуацию» [Гуревич, 2008, с. 146].Такие предикаты имеют аксиологический характер, т.е. содержат в себе либо комплексную оценку прецедентной коммуникативной ситуации, либо оценку отдельных ее компонентов: участников, референта, сценария или содержания коммуникации и т.п.

Рассмотрим два примера, которые имеют значение «сообщение Марии информации Петром о злой собаке во дворе». В представленных ниже предложениях оба глагола сообщают информацию и номинируют одну и ту же речевую ситуацию. Ср.:

(1) X1: Петр говорит Марии о злой собаке во дворе.

(2) X2: Петр предупреждает Марию о злой собаке во дворе.

Необходимо отметить, что Петр в передаваемой ситуации был говорящим, но данное выражение порождает некий наблюдатель (X). В предложении (1) сообщение адресата адресанту передается при помощи предиката говорить. Базовый в иерархии глаголов речи предикат говорить является гиперонимом для глаголов имеющих более конкретное значение, например, таких как предупреждать, советовать, угрожать, намекать и др. Наблюдатель (Х) в примере (1) производит констатацию факта, он не вкладывает никакого своего собственного мнения, не даёт своей оценки происходящего. С позиции наблюдателя, занимающего по- 
ложение вовне, те же самые сущности, находящиеся во владении индивидуума, определяются по-иному, добавляются личные, прецедентные знания. В предложении (2) говорящий ословливает ситуацию, придавая ей свою собственную оценку, он не просто передает информацию, а категоризует ее именно как предупреждение.

Процесс общения людей в ряде случаев можно представить поэтапно: сначала происходит коммуникация т.е. получение новой информации, затем ее осмысление (когниция) человеком, приобретшем новое знание и, как обратная реакция, происходит метакоммуникация. Во внимании процесса коммуникации находится адресант, а метакоммуникации - адресат с его реакцией на некую предыдущую ситуацию высказывания. Метакоммуникация как результат осмысления предшествующего ей коммуникативного акта нацелена на описание самой ситуации общения, оценку его на предмет удачности / неудачности. Восприятие и ментальная обработка поступающей новой информации человеком зависит от его внутренних факторов, здесь можно говорить о языковой личности говорящего.

Метакоммуникативное высказывание адресанта практически всегда содержит оценочные характеристики относительно участников предшествовавшего коммуникативного акта, их коммуникативной деятельности и устремлено на то, чтобы вызвать поддержку собственного мнения у собеседника, на подтверждение собственной оценки коммуникативного акта на предмет удачности или неудачности. Метакоммуникативное высказывание не является самопроизвольным, его появлению предшествуют некоторые закономерности диалогического дискурса.

Рассмотрим пример, в котором используется метакоммуникативный предикат warn в аннотации к статье газеты «The Washington Post», где сообщается, что Иран предупредил американские силы в Ираке о том, что последует ответ на любое нарушение иранского воздушного пространства (a).

(a) Iran warned U.S. forces in Iraq on Wednesday that it would respond to any violation of Iranian airspace, a message analysts said seemed directed at the new U.S. president-elect more than neighboring American troops. - Иран предупредил американские силы в Ираке в среду, что последует ответ на любое нарушение иранского воздушного пространства...

Анализируемая статья основана на данных иранской радиостанции, опроса иранских политических деятелей, местных жителей, а также личной интерпретации журналистом располагаемой информации. В приведенных автором цитатах отсутствует эксплицитное предупреждение, т.е. употребление предикатов предупреждения ${ }^{1}$, однако журналист интерпретирует имеющиеся факты именно как предупреждение (a), что обусловлено его субъективной трактовкой ситуации. Мы полагаем, что в располагаемой информации автором содержаться компоненты ситуации предупреждения, благодаря наличию которых он делает выводы и категоризирует ситуацию именно как предупреждение. В рассматриваемой статье можно выделить следующие компоненты: СУБЪЕКТ1 (предупреждающий), СУБЪЕКТ2 (предупреждаемый), ОТНОШЕНИЯ предупреждения, СОДЕРЖАНИЕ (то о чем предупреждают), ОПАСНОСТЬ и ЦЕЛЬ (МОТИВ). Как может показаться, предупреждающим и предупреждаемым являются правительства конфликтующих стран: СУБЪЕКТ1 - Иран, СУБЪЕКТ2 - США, но в данном примере предупреждение относится непосредственно к личности только избранного президента Борака Обамы. Об этом свидетельствует несколько приведенных цитат:

1 Семантика предиката позволяет представить ситуацию более обобщенно. Е.С. Кубрякова полагает, что предикаты представляют собой «компактные наименования ситуаций и структур деятельности» и могут более ёмко, но с наименьшими затратами лексики, представить ситуацию [Кубрякова, 1985]. 
(b) But an Iranian politician said the timing suggested it was directed at Barack Obama, who won Tuesday's U.S. vote ... - Но иранский политик сказал, что выбор времени наводит на мысль, что это было направлено Бараку Обаме, который выиграл американское голосование во вторник ...

(c) This is a clear message to the American president-elect ... - Это - сообщение открытым текстом американскому избранному президенту ...

В сообщении иранской радиостанции, приводимом автором статьи, говорится об ответных военных действиях (d). СОДЕРЖАНИЕМ предупреждения являются ответные действия страны, чьи границы были нарушены, иными словами угроза начала военных действий между государствами.

(d) "Iran's armed forces will respond to any violation," radio said, citing a statement from Iran's army headquarters. - «Вооруженные силы Ирана ответят на любое нарушение», - сообщило радио, цитируя заявление из армейского штаба Ирана.

Предупреждение, как и другие сознательные виды деятельности, также является целенаправленным, поэтому ЦЕЛЬ является важным компонентом. ЦЕЛЬЮ в данной ситуации предупреждения, как мы полагаем, является не допустить нарушения границ своего государства. Однако даже если учесть, что данное предупреждение, по мнению аналитиков, в большей степени относилось президенту США, можно сказать, что ЦЕЛЬ предупреждения - попытаться заставить президента пересмотреть политику агрессивного отношения к другим странам (е).

(e) Iranian government spokesman Gholamhossein Elham said he hoped Obama would make "fundamental changes in the approach of the United States toward global issues" and end "aggression toward other countries," state broadcaster IRIB reported. - Иранский представитель правительства Голэмхоссейн Элхэм сказал, что надеется, что Обама сделает «коренные изменения в подходе Соединенных Штатов к глобальным проблемам» и покончит с «агрессией в других странах»сообщила государственная вещательная организация IRIB.

Компонент ОПАСНОСТЬ выделяется нами на основании того, что изучив многие примеры с предупреждением, мы отмечаем его обязательное наличие, как и в этом примере (f).

(f) "Recently it has been seen that American army helicopters were flying a small distance from Iraq's border with Iran and, because of the closeness to the border, the danger of them violating Iran's border is possible," state radio reported. - «Недавно было замечено, что американские армейские вертолеты летали на небольшом расстоянии от границы Ирака с Ираном, из-за близости с границей, опасность того, что они нарушат границу Ирана, возможна ... »

Выделенные компоненты ситуации соотносятся со слотами ранее построенного нами фрейма «предупреждение». Под фреймом понимается «мыслимый в целостности его составных частей многокомпонентный концепт, объемное представление, некоторая совокупность стандартных знаний о предмете или явлении» [Попова, Стернин]. Структура фрейма содержит в себе облигаторные (обязательные) слоты (компоненты), заключающие в себе информацию, достоверную для прототипической (типичной) ситуации, а также необлигаторные (факультативные) компоненты, которые включаются в зависимости от конкретной ситуации.

В статье во всех приведенных источников используются предикаты say (сказать), report (докладывать) и tell (говорить), которые в аннотации статьи журналиста «переходят» в метакоммуникативный предикат warn, т.е. «сказал» становится «предупредил». Безусловно, журналист данного жанра должен быть максимально объективным, однако в любом случае, располагая какой-либо информацией, интерпретирует ее через призму своего субъективного понимания (его оценка ситуации). Предикат warn включает в себя все компоненты, и адресат данного высказывания сразу понимает ситуацию. Полагаем целесообразным более углубленное изучение предикатов и выделение большого пласта метакоммуникативных 
предикатов, которые представляют собой группу метаязыковых единиц, отличающуюся некоторыми функциональными и структурными свойствами, позволяющими определить их особое место в диалогическом дискурсе.

\section{Литература}

Апресян Ю.Д. Избранные труды. Интегральное описание языка и системная лексикография. М., 1995. Т. 2. С. 199-241.

Арутюнова Н.Д. Типы языковых значений: Оценка. Событие. Факт. М., 1988.

Вендлер 3. Иллокутивное самоубийство // Новое в зарубежной лингвистике. М., 1985. Вып. 16: Лингвистическая прагматика. С. 228-250.

Гуревич Л.С. Когнитивное пространство метакоммуникации. Иркутск, 2009.

Ковалева Л.М. Коммуникативные предикаты в синтаксической и семантической организации предложения // Проблемы филологии в синхронии и диахронии. Сборник статей к юбилею профессора Л.А. Глинкиной. Челябинск, 2005. С. 178186.

Крылов С.А. О содержании термина «предикаты пропозициональной установки» // Пропозициональные предикаты в логическом и лингвистическом аспекте: Тезисы докладов рабоч. совещания. М., 1987. С. 71-73.

Кубрякова Е.С. Коммуникативные единицы языка // Коммуникативная лингвистика и проблемы семантики. М., 1985. Вып. 252. С. 138-151.

Попова З.Д., Стернин И.А. Когнитивная лингвистика. [Электронный ресурс]. Режим доступа: http://zinki.ru/book/kognitivnaya-lingvistika (дата обращения 28.03.12).

Проскурин С.Г. Тематическая сеть языка и культуры. [Электронный ресурс]. Режим доступа: http://www.nsu.ru/education/virtual/cs014proskurin.pdf (дата обращения - 15.04.12).

Austin J.L. How to Do Things with Words. Oxford, 1965.

The Washington Post - URL: http://www/washingtonpost.com (дата обращения $-17.10 .2009)$. 